DOI: $10.17516 / 1997-1370-0355$

УДК $394,81-2$

\title{
The Image of the Water Element in the Yakut People's Minds: Cultural Experience
}

\author{
Anna N. Ikonnikova, Irena S. Khokholova \\ and Kiunnei A. Pestereva* \\ M.K. Ammosov North-Eastern Federal University \\ Yakutsk, Russian Federation
}

Received 07.11.2018, received in revised form 27.11.2018, accepted 11.12.2018

\begin{abstract}
It involves the interdisciplinary approach (linguistics, psycholinguistics, cultural studies, history, ethnology, sociology, and geography). The research methods include the method of free and directed associative experiment, the method of semantic gestalt, and the method of questioning. Basing on the associative thesaurus of the Yakut language and a social survey among the population of Yakutia, the authors reveal the image of water elements in the minds of the Yakuts. As a result of the research, it was proved that for modern population the image of water elements is closely related to the region's geo-landscape and climatic features. The image of the river is the main landmark in space. It is associated with movement and dynamics in time. The image of the ice drift is closely related to the region's climatic conditions and landscape features, which affect the spring (seasonal) natural elements, as well as the life cycles - letting the past go and starting a new life, characteristic of the southern Turkic culture. The image of the ice drift in the Yakuts' minds is perceived through the prism of spontaneity and danger of the river as a whole.
\end{abstract}

Keywords: image of the river, language consciousness, river, gestalt, ice drift, element, flood, indigenous population, Yakutia.

The research has been supported by the Russian Science Foundation grant No. 15-1820047 "Landscape Ontology: Semantics, Semiotics, and Geographical Modeling".

Research area: philology.

Citation: Ikonnikova, A.N., Khokholova, I.S., Pestereva, K.A. (2018). The image of the water element in the Yakut people's minds: cultural experience. J. Sib. Fed. Univ. Humanit. Soc. Sci., 15(4), 434-442. DOI: $10.17516 / 1997-1370-0355$.

(C) Siberian Federal University. All rights reserved

* Corresponding author E-mail address: an.ikonnikova@s-vfu.ru; iskhokholova@mail.ru; yu00ika42@gmail.com 


\section{Introduction}

The image of the water elements and the image of the river and its elements in particular have been of key importance in the life of the Yakut people. The studies focusing on their interpretation in the linguistic consciousness of certain groups provide an opportunity to reveal the picture of the world peculiar for modern residents of Yakutia.

The archaeological researches prove that from the Stone Age the ancient tribes preferred to settle near large rivers, where natural conditions were suitable for maintaining hunter-gatherer economy. Settling in the riverside areas, people were always tied to the geographical environment with the river as its centre. The population's strong dependence on the water element contributed to the formation of a special sacred topography, the river being its central object as it facilitated the movement and was a source of food. The river also was an environment full of dangers. Being the source of life, from which all life on earth originated, the reservoir was simultaneously perceived as a nominal boundary between the world of the living and the world of the dead (Danilova, 2015). This concept of the water goes back to the archaic cosmogonic narratives, which are, in general, comparable to those of many peoples of Eurasia. The land itself and everything living on it originate from the water as a result of various manipulations of mythical creatures and deities. Yet, the water also has the opposite meaning, the meaning being that of hostile environment that brings mortal danger (Prokop'eva, 2018). Hence, the ambiguous, ambivalent attitude towards the water is expressed in certain taboos and rituals regulating a human's daily actions. Thus, it serves as a common practice to refer to the river or lake "Ebe" (grandmother) respectfully, without saying the name of the water body aloud. In the ideas of afterlife the Siberian peoples, including the Yakuts, have the lower world is located in the mouth of the river in the north (Fedorova, 2007). This, probably, had determined the custom to bury the dead in the direction towards the river, since it could serve as a road to the lower world (Bravina, 2008). The signs of this position of the dead and their location on high river terraces were found on a number of Neolithic funerary monuments, which indicates the importance of the river in the burial rite and the ancient Yakut cultures (Kozlov, 1980; Mochanov et al., 1983; Fedoseeva, 1988).

The key geographical object in the landscape of Yakutia is the Lena River with its numerous tributaries. The Lena and other rivers were of particular importance for the Yakut people from ancient times: they were the sources of food and the main routes by which the territory of Yakutia was settled. The Lena River is the largest river in Eastern Siberia. It flows from the western slope of the Baikal Range through the territory of the Irkutsk Region and Yakutia with their permafrost and runs into the Laptev Sea.

\section{Theoretical framework}

J. Jiles and T. Middleton (Giles, Middleton, 2008) point out a certain relationship between culture and history. They consider history as a "key practice in the cultural processes", "one of the aspects of culture and identity". They further explain the role of history while noting that "it helps us find tracks of the past in the present, therefore understand the world better" (Giles, Middleton, 2008). Reflecting on the representation of history, F. Anbaran Fakhimi argues that, "today we may receive the representation of the process, with which the sense generates and spreads" (Anbaran Fakhimi, 2016).

There is obviously certain connection between the history of nation and the environment. The space and surrounding events play significant role in modeling the image of the world of culture. This image reflexively relates it to the surrounding landscape and is associated with the main contacts and culture codes. According to Semen V. Lurje, "ethnic tradition, along with ethnic representation of the world as its component, has certain unchangeable elements... These are neither beliefs nor values, but adaptation and activity models which constitute "the core of the culture" in the surrounding world (Lurje, 1998). Lurje confirms that "during the process of ethnos formation the representation of the world may change but "what remains unchanged are ethnic con- 
stants as subconscious elements" (Lurje, 1998). "They are certain mechanisms that lower down the psychological pressure from the surrounding world and provide the individual with the ability to act" (Lurje, 1998).

Therefore, consciousness of a specific ethnic group mirrors the peculiar features of their interaction with the world. The analyses of forms of expression of linguistic consciousness allows to explore the explicit cultural matrix of certain ethnos during a certain period in history.

The associative structure of geographic objects modeling shows not only primary knowledge which is fixedly attached to geographic objects and toponyms. It also demonstrates the cultural experience of the society towards landscape and geographical space as well as new knowledge gained through this experience and fixed in the language.

The image of the object is considered in this article on the basis of the developed dictionary of free verbal associations. L.S. Zamorshchikova and I.S. Khokholova note: "The dictionary data base allows to: 1 . Investigate the peculiarities of the world view, and the linguistic consciousness of the ethnos living in a multicultural and multilingual context; 2 . Reveal the elements of the traditional world view, derive the content of cultural world views, its cultural specificity and uniqueness; 3 . Fixate and thereby preserve these indicators of ethnic mentality for the transmission to the future generations" (Zamorshchikova, Khokholova, 2016).

The associative thesaurus is a verbal material that has its semantic content and exists in every human's mind. According to T.N. Ushakova, "verbal network functions as an integral "quasispace". All elements of quasispace are closely linked. Verbal network is like an eternal spiderweb. Its organization is of a complex structure that keeps big amount of semantic relations" (Ushakova, 2011). Gemma Bel Enguix, Reinhard Rapp, Michael Zock notice that "the corpus-derived associations are evaluated using a large test set comprising several thousand stimulus/response pairs as collected from humans. The finding is that there is a high agreement between the two types of data. The con- siderable size of the test set allows us to split the stimulus worlds into a number of classes relating to particular word properties" (Enguix, Rapp, Zock, 2014).

N.V. Ufimtseva argues that one of the advantages of the associative reactions research is that "these materials can be considered as the "associative profile" of images specific for a certain culture and language. They integrate mental and sensual knowledge of a certain ethnos" (Ufimtseva et al., 2004).

Associative-verbal network (a term suggested by Iu.N. Karaulov) is a psychological foundation of language knowledge. It is a combination of phonetic, semantic, grammar, lexical and associative links. The associative-verbal network reveals the specificity of linguistic consciousness as associations disclose the processes in human mind. Texts do not only surround a human, they are also embodied in his/ her individual associative-verbal network. Identification of the associative-verbal network is possible due to the associative experiment. Iu.N. Karaulov claims that "it is the remote regularity (not the surface one) that is inspired and is, eventually, under the control of the same texts circulating in the society, thus daily going through individual linguistic consciousness and reinforcing a genetically formed links in an individual's associative-verbal network" (Karaulov, 2002).

All associations can be classified by applying the "semantic gestalt" method (Iu.N. Karaulov) to reveal the image of an object of interest. Supporting Iu.N. Karaulov's ideas, I.S. Khokholova states that "the semantic gestalt of the associative field appears when the associates are attracted to certain characteristics bunching together around several reactions that denote a certain set of mental images - concepts" (Khokholova, 2013). Every associative field is divided into groups. Each group is named according to the characteristic of the semantic zone of the gestalt marking the group's reactions as well as the rank" (Khokholova, 2013).

\section{Results and discussion}

We studied the image of the river basing on the material of the Yakut associative dictio- 
nary. The respondents had to react to "river" as a stimulus word. By means of the semantic gestalt and on the basis of the results of the Yakut associative material we obtained the associative model of the image of the river in the mind of Central Yakutia residents. The whole life that is associated with the river, the attitude to the river, its qualitative features, and the role it has been playing in the people's life are reflected in the linguistic consciousness of the Yakut people. The study of the image of the river in the linguistic consciousness of the Yakuts, according to the results of the Yakut associative experiment (2010), showed that the structure of the "river" semantic gestalt includes the following groups: "object" (42.26\%), "toponymy" (18.40\%), "characteristic feature" (13.11\%), "direction, move-

Table 1. The respondents' reactions to the stimulus "river" as based on the material of the Yakut associative dictionary

(L.S. Zamorshchikova, A.A. Romanenko) (Zamorshchikova, Romanenko)

\begin{abstract}
o e r u s $u$ (water) 307; The Lena 61; kjuel (lake) 59; Bjuljuu (the Vilui river) 48; sjujurjuk (current, duct) 43;
(river) uhun (long) 41; ebe (grandmother (respectful attitude) 40; jurekh (stream, river) 39; balyk (fish) 35 ; muora (sea) 31; Oeluoene (the Lena river in Yakut version), ustar (flows) 28; yraas (clean, pure) 25; diring (deep), kieng (wide, broad), ulakhan (big) 15; muus (ice) 14; Amma (the Amga river in Yakut), unguor (through, on the reverse side) 11; soetuoeleehin (bathing) 9; Bjuljuu oerjus (the Vilui river), dolgun (wave) 7; Lena oerjus (The Lena river), parom (Russian word) ferry, taas (stone), tymnyy (cold), ulakhan uu (big water) 6; olokh (life), sajyn (summer), soetjuoe (bathing), sjuurjukteekh (with the flow, fleeting), tjurgen (fast), elbekh uu (high water) 5; kumakh (sand), kjuoekh (green), kytyl, ustuu (current, flux), estiite (ice drift), ester (ice shove) 4; Aldan (the Aldan river), aryy (isle), bajgal (ocean, sea), bierek (coast), dojdu (land), kuttallaakh (dangerous), sjuurer (flows, runs), sjuureen (current, cycle), ulakhan kjuel (the big lake) 3; Amma oerjus (the Amga river), balyktar (fish), bereg (coast), bierege (coast of), voda (water in Russian), kjuus (power, might), ojuur (forest), oerjus (river), reka (river in Russian), soetjoeljuu (to swim), suol (road, way), sjuurjukteekh uu (fast flowing water), tyal (wind), usta turer (is flowing), ustun (along), uuta (water of), khallaan kjuoekh (blue), estere (ice drift) 2; ajannyyr sirim (the way I drive), ajylga (nature), ajyma (don't invent), araastara (various, diverse), baaj (wealth), balyksyt (fisherman), baryy (departure, exit, death), biirge (together), birieme (time), Bjuljuu oerjuhe (the Vilui river), byyhaa (save, help), gory (mountains in Russian), dalaj (to swim or to pass across), diring uu (deep water), dojdubun (my homeland, motherland), dojdulaahyn (my home way), dokhsun (rapid, fast), Djaangy (the Yana river), djenkir (clear, crystal), ije (mother), ikki angy (from two sides, on both sides), Indigir (the Indigir river), irbit (thawed), kirbii (watershed, border), kirdeekh (dirty), kirdeekh Lena (the dirty Lena river), kieng (wide), kujaar (the endless horizon, endless space), kjuljumjurdes uu (brilliant water), kumakhtaakh (sandy), kjuoes (food that is cooked), kuta (bog), kjuusteekh (powerful), kyra (little), kyys (girl), ketit (wide), lodka (Russian word, boat), Maja (Maja), mangan (white), Markha (Yakutsk district), mas (tree), mnogo vody (Russian word, mush water), muus ustara (debacle), muus khaja (ice block, mountain), Nile (the Nile), nengjuoe ustuu (raft, float), oegulleges (branched, branch), ozero (Russian word, lake), oeljuu-sjutjuu (death), parokhod (steamer), r. lena, saas (spring), sajyngy kiehe (summer evening), salaata (inflow, creek), silis (root), sin'iges (thin), skamejka (Russian word, bench), soerjuun (cool), Suntaar (Yakut village), suol sabyllyyta (road closure), syurukteekh (flowing), suure turar uu (flowing water), sjuureenneekh (with flow), syn'alang (rest), syrdyk (light), taastar (stones, rocks), Taatta (Yakut village), talakh (branch), techenije (Russian word, flowing), timirbit (drowning), toegjurjuk (round), tongmut (frozen), tokhtolo suokh (unceasingly), tramwaj (tram), turba (tube), tya (forest, taiga), tyas (noise, crackling), uje (century), ulakhan balyk (a big fish), ulakhan oerjus (a big river), uluu (great), unguor kihi turar (a man is on the reverse side), uoehe (high, upstairs), ustar uu (running water), usta sytar uu (water current), ustubut (flowed), ustuu-umsuu (swimming, diving), uulaakh (abounding in water), uullara (defrosting), uuta yraas (clean water), uu ustar (water flows), uhun uu (a long water), khaamyska (pebble), khara (black), khomolto (sadness), khonuu (field), khocho (valley), charang (birch grove), yp-yraas (clean), yraas uu (clean water), elbekh (mush), estibit (ice shoved), Yana (the Yana river) 1
\end{abstract}

$(1220,171,61,105)$ 
ment, time" symbolism (6.98 \%), "seasonality, weather" (5.48 \%), "river formations" (5.19\%), "sacredness" (3,86\%), "composition features" $(1.32 \%)$, "activity" $(0.56 \%)$. The river is primarily objectified in the Yakut respondents' linguistic consciousness. Objectification that reflects the knowledge of the surrounding world is explained by the determining influence of natural conditions and landscape space on the respondent's associative selection. The image of the river appears as an object and is associated with other water bodies: water (uu 307 reactions), lake (kjuel - 59 reactions), river, stream (urekh - 39 reactions), sea (muora) - 31 reaction), etc.

The image of the river in the respondents' mind is based on the "characteristic features" of the river that is due to their dependence on the people's life and activity, needs and motives. The landscape of the whole territory, land management, land use, road infrastructure, a vital industry such as agriculture in central regions, fishing in northern regions (ulus) (Prokop'eva, 2018) are largely dependent on the river and its characteristic featuress. Greatness and power of the river in the people's linguistic consciousness is determined by its primary qualitative characteristics (long (uhun), deep (diring), large, huge (ulahan), flowing, running, fleeting (sjuurukhteh, tjurgen)), natural and climatic characteristics (cold (tymnyy), ice, ice cold (muus)), those of its ecological compatibility (clean (yraas), etc.

Furthermore, the frequent reactions that have formed the "toponymy" group in the structure of gestalt are the names of rivers (potamonyms), locations (oikonyms) in Yakutia: the Lena (61 reactions), Oeluoene / the Lena (28), the Lena / Lena oerus (6), Buluu / the Vilui (48), Buluu oerus / the Vilyui River (7), Amma / the Amga (11), etc. Toponyms are represented by hydronyms and oikonyms of the respondents' local territory, the only exception being one reaction (the Nile river) that relates to general physical geo-toponymy.

In the structure of the semantic gestalt a sufficiently large "river formations" group is singled out: current, channel, (sjuuruk 41 reactions), wave (dolgun), running water (sjuurjuktekh uu).
A core group of the associative field of the word "river" is its "movement, time, direction" symbolism (for example, such frequent reactions as flows (ustar), current (ustuu), life (olokh), road (suol), runs (sjujurer), and single reactions as time (birieme), period, segment (kirbii), century (uje), the road I drive along (ayannyyr sirim), swim across (nenguoe ustuu), in halves, in a spread, from two sides (ikki angy), etc. The Lena River is a connecting waterway between the regions of Central Yakutia. As the main landmark in space the river characterizes not only the landscape features, but also its dynamics in time and in space. The dynamics of the river resemble life, road, striving for the future, or death. A special attitude to understanding of life-death can be described as ethnic constants, the collective subconscious, which pass from generation to generation at subconscious level. The "movement, time, direction" associative field is, thus, directly connected with that of "sacredness".

The associative fields "sacredness", "composition features" and "activity" occupy the periphery in the respondents' associative-verbal network. The frequent response revealed in the associative field "sacredness" is "ebe" (40). It is caused by a respectful attitude to the river. "Ebe" (grandmother) as the nomination of a lake or a river has a sacred meaning in the Yakut culture. The Yakuts refer to or name the river as "ebe" instead of using its name. This symbolizes respect and honour. In the Yakut culture the name of the river should be viewed as a taboo, dating back to the Yakut beliefs about attracting misfortune, the wrath of the spirit of a lake or a river. As for the single reactions revealed in the associative field "sacredness", these are "oeluu-sutuu" (death, doom loss) and "homolto" (bitterness, grief, trouble). These single reactions are probably associated with its spontaneity, danger, or such archetypal Yakut sacral ideas associated with the image of the river as a road to the world of the dead the soul of the deceased should go along.

"Seasonality" characterized by the landscape and climatic features of the region - ice (muus), coming off (ester, estere), freezing-over (estiite), bathing (soetuleehin, soetue), to bathe (soetue), summer (sajyn), wind (tyal), etc. - is 
of particular importance in the Yakut people's life. The Lena River is one of the largest rivers flowing along the territory of permafrost. So, the geo-landscape and climatic conditions directly affect the formation of the image of seasonal features, processes or changes - ice drift, freezing-over, flooding, etc., which the Yakuts' lifestyle depends on.

The key concept in the Yakut people's life which relates to the water elements - the image of the ice drift in the linguistic consciousness of Central Yakutia residents - was a subject of the research in April, 2017. A sociological survey - the directed associative experiment via a Google Form with built-in response statistics, the interviewing (audio documentation of the respondents' answers on site) - was chosen as the research method. The age of the interviewees ranges from 20 to 60 years old, the age of 20-35 being predominant since it is the most active age for participation in online surveys. The majority of the respondents are residents of Yakutsk city $(85.3 \%)$. For $13.3 \%$ of the respondents the city is a temporary place of residence. $68 \%$ of the respondents were females, $32 \%$ were males. The ethnic composition is represented mainly by the Yakut and Russian respondents.

The questionnaire focused on the following aspects: age, nationality, place of residence, type of the respondents' activity (position), associations with the ice drift, the reasons to come and watch the ice-drift, any beliefs related to the ice drift, any rites performed by the respondents during or after the ice drift, the respondents' thoughts about natural spontaneous consequences during or after the ice break-up in the republic.

Most of the respondents who identified themselves as students associate the ice drift with the arrival of spring. For $47 \%$ of the respondents the ice drift is the arrival of spring, warmth and the beginning of the wind season. $4 \%$ of the respondents of the older generation associate it with the renewal of the cycle (life cycle). $6 \%$ of respondents state that the ice drift is associated with danger, natural disasters, ice drift, and destruction. $7 \%$ of respondents called childhood and pleasant dreams to their memories, whereas $20 \%$ relate the ice drift to economic factors (unavailability of ferry transportation, temporary suspension of cargo, etc.). In order to avoid damage from the flood, the residents of some riverine settlements are forced to carry out seasonal activities and move their property to flood-free areas. The situation when the village of Kyllakh was moved to the village of Dapparai in Olyokminsky region (ulus) and, consequently, caused certain economic and social problems can serve an example of a radical solution of flood problems (Vinokurova et al., 2016).

People go to observe the ice drift to feel the unity with nature (3\%), enjoy the beauty and awakening of nature after a long winter (20\%), feel the strength and power of the river (9\%). $10 \%$ cannot formulate the reason, but do it annually or every few years. $16 \%$ of the respondents explain their desire to observe the ice drift by the lack of other leisure activities in the city. Other reasons mentioned are coping with stresses, getting renewed and more energetic $(15 \%)$, family traditions kept up from childhood $(7 \%)$. Keen interest to the process when the river is getting free from ice is recently peculiar for $8 \%$ of the respondents ("for taking a photo", "everybody goes", "a matter of fashion"). Romance, love, and strengthening family relations were mentioned by $4 \%$ of respondents. The positive impact of the ice drift ("to be charged with energy") was mentioned by $18 \%$ of respondents. It should be noted that most of the respondents on the site of the ice drift mentioned that they had lived near the river before.

A large number of the respondents (56\%) mainly at the age of 25-35 could not name any traditions or beliefs associated with the ice drift. $44 \%$ (predominantly at the age of 5069) pointed out that being present near the river during the ice drift is a taboo as the river takes away one's life energy along with the ice. It is, probably, due to this that $24 \%$ of the respondents think that there should be performed a ritual of purification and "feeding" the river ("we've heard", "it's traditionally believed"). The ritual of "feeding" the river refers us to the "transmission of cultural codes through symbolic practices" of northern peoples (Romanova, 2015). "During the ice drift the Yukagirs 
performed the ritual of "feeding the river" and prayed for their people's safety, sang special songs, presented beads as gifts, and offered coins to gain the river's favor". Evidently, at present "feeding" the river with griddle cakes relates to the northerners' beliefs and rituals (Pluzhnikov, 2010) that have eventually become a symbolic practice for gaining the river spirit's favor in the Yakut culture. Since the Yakuts had beliefs related to the spirit of water, in spring and autumn they sailed tiny boats down the river. The boats were made of birch bark, and there was an image of a human in the middle. They also hanged salama (the bands made out of horsehair) (Alekseev, Romanova, Sokolova, 2012). These beliefs were most likely associated with the life cycle - letting all evil and everything that had piled up over the past year (over the course of a long, harsh winter) go and asking the river for new life energy and strength in the coming summer, which might be associated with the genetic memory of the south. Despite the fact that these rituals are not reflected in the responses, the respondents still mention a general idea of this belief of the life cycle, letting the evil (past) go and looking forward to promising future.

The absolute majority of the respondents (99 \%) associate the ice drift with the natural elements (wind, flood). It is explained by climatic and economic specific features of the territory. "A spring flood is a distinctive feature of northern rivers". Spring floods are caused by climate conditions and particular characteristics of the landscape and water resources forming the waterway of the North. According to E.N. Romanova, an ethnographer and ritual mythologist, these factors are reflected "in the northerners' mythology explaining the cause of the flood", which is associated with the fact that the river flows into the Arctic Ocean (Romanova, 2015). The floods, in turn, cause a major blow to the socio-economic situation in the region, since they flood the settlements located near the river and, thus, cause damage - underflooding of houses, facilities, and territories used for agricultural purposes, cattle mortality, disruption of communications between the villages (destruction of bridges, dams and roads).

\section{Conclusion}

The associative structure of geographical objects modeling demonstrates not only primary knowledge of geographical objects and place-names, but also the society's cultural background covering the knowledge of a landscape or geographical space as well as the new knowledge gained through this experience and fixed in the language. The picture we observe presents quite an entire image of water elements: the very image of the river and the image of the ice drift, the image containing the gained meaningful cultural experience in its geocultural decoding and fixed in the linguistic consciousness of the Yakuts. Landscape is a landmark with the water objects as the key ones - settlement along the river and the rivulets is explained by practical-and-social and economic reasons. For modern Yakut residents the image of the river is primarily associated with its following characteristics: greatness and power, landscape and climatic features of the region, seasonality, its dynamics, and its direction in time and space. The image of the ice drift stems from the perception related to the region's climate conditions and landscape specificity, which influence the spring (seasonal) nature elements, and to the life cycle - letting the past go and starting the new life which is peculiar for the southern Turkic culture. Generally, the image of the ice drift in the native Yakuts' linguistic consciousness is expressed in the light of the river elements and the danger the river might cause. In order to prevent the spontaneity of the water during the spring flood they perform a ritual of feeding the river. It traces to the faiths of northern Siberian peoples which later penetrated into the Yakut culture. In the course of time, these faiths and values receded into the background of the southern Turkic (Yakut) culture that found itself in severe northern climate conditions and faced the region's natural climate and landscape specific features, including the water elements and the threat and danger coming from the river. This is largely because of a key importance of "adaptation and activity models" for a human's further life activity in the surrounding world. 


\section{References}

Alekseev, N.A., Romanova, E.N., Sokolova, Z.P. (2012). Iakuty [The Yakut people (Sakha)]. Moscow, Nauka, 559 p.

Anbaran Fakhimi, F. (2016). "A Whole Way of Life”: Ontology of Culture from Raymond Williams's Perspective. In International Letters of Social and Humanistic Sciences. Available at: https://www.scipress. com/ILSHS.67.46.pdf (accessed 2 September 2018)

Bravina, R.I. (2008). Pogrebal'no-pominal'naia obriadnost' iakutov: pamiatniki i traditsii (XV-XIX $v v$.) [Exequial and memorial ritualism of the Sakha people: heritage and traditions $\left(15^{\text {th }}-19^{\text {th }}\right.$ centuries)]. Novosibirsk, Nauka, 296 p.

Danilova, N.K. (2015). Vodnye ekosistemy: prostranstvennye predstavleniia i dukhovnyi universum (po etnograficheskim materialam naroda sakha) [Aquatic ecosystems: spatial representation of spiritual universe (study of ethnographic materials of the Sakha people)]. In Teoriia i praktika obshchestvennogo razvitiia [Theory and the practice of social development], 16, 160-163.

Enguix, Bel G., Rapp, R., Zock, M. (2014). A Graph-Based Approach for Computing Free Word Associations. Language Resources and Evaluation. Available at: https:/www.researchgate.net/publication/307513251_A_Graph-Based_Approach_for_Computing_Free_Word_Associations

Fedorova, E.G. (2007). Reka v pogrebal'noi obriadnosti narodov Sibiri [The river in the funeral rites of the Siberian people]. In Reki i narody Sibiri [Rivers and peoples of Siberia]. Saint Petersburg, Nauka, 216-237.

Fedoseeva, S.A. (1988). Diring-Iuriakhskii mogil'nik (ograblenie mogil i problema zarozhdeniia pervobytnogo ateizma [Diring-Iuriakhskii burial ground (tomb robbery and the issue of the genesis of primordial atheism)]. In Arkheologiia Iakutii [Archeology of Yakutia], Yakutsk, 79-98.

Giles, J., Middleton, T. (2008). Studying Culture: A Practical Introduction. The USA, Wiley, 324 p.

Karaulov, Iu.N. (2002). Russkii assotsiativnyi slovar': v 2-kh tomakh [Russian associative dictionary: in two volumes]. Moscow, 1, 750-782.

Kozlov, V.I. (1980). Novye arkheologicheskie pamiatniki Amgi [Recent archeological monuments of the Amga River]. In Novoe v Arkheologii Iakutii [New in the Archeology of Yakutia], 55-62.

Khokholova, I.S. (2013). Chitatel'skie kontseptual'nye proektsii "muzhestvennost"" i "zhenstvennost"” v mezhkul'turnom obshchenii (na materiale iakutskogo eposa "Nurgun Bootur Stremitel'nyi” [The readers' conceptual projections of "masculinity" and "femininity" in cross-cultural communication (as exemplified by Yakut epic "Nurgun Botur the Swift")]. In Sibirskii filologicheskii zhurnal [Siberian Philological Journal], 2, 69-76.

Lurje, S.V. (1998). Istoricheskaia etnologiia. Uchebnik dlia vuzov [Historical ethnology. University textbook]. Available at: http://www.gumer.info/bibliotek_Buks/History/Lyrie/53.php

Mochanov, Iu.A., Fedoseeva, S.A., Alekseev, A.N., Kozlov, V.I., Kochmar, N.N., Shcherbakova, N.M. (1983). Arkheologicheskiie pamiatniki Iakutii: basseiny Aldana i Olekmy [Archeological monuments of Yakutia: the Aldan and Olekma basins]. Novosibirsk, Nauka, 391 p.

Nikitina, S.E. (1993). Ustnaia narodnaia kul'tura i iazykovoe soznaniie [Oral culture and linguistic consciousness]. Moscow, Nauchnoe izdanie, $187 \mathrm{p}$.

Pluzhnikov, N.B. (2010). Dukhovnaia kul'tura [Spiritual culture]. In Narody Severo-Vostoka Sibiri [Peoples of North-Eastern Siberia]. Moscow, Nauka, "Iukagir”, 668-677.

Poplinskii, Iu.K. (2007). Rechnye kultury i stanovlenie tsivilizatsii [River cultures and the formation of civilizations]. In Reki i narody Sibiri [Rivers and peoples of Siberia]. St.-Petersburg, Nauka, 5-18.

Prokop'eva, A.N. (2018). Rechnye liudi: zhizn' na beregu reki Lena [The river people: life on the bank of the Lena River]. In Vestnik SVFU [The NEFU Reporter], 1 (09), 23-29.

Romanova, E.N. (2015). Sever v biograficheskom narrative [The North in the biographical narrative (autoethnography experience)]. Yakutsk, Arctic State Institute of Arts and Culture, 13-15.

Ufimtseva, N.V., Cherkasova G.A., Karaulov Iu.N., Tarasov E.F. (2004). Slavianskii assotsiativnyi slovar': russkii, belorusskii, bolgarskii, ukrainskii [Slavic associative dictionary: Russian, Belorussian, Bulgarian, Ukrainian]. Moscow, 800 p. 
Ushakova, T.N. (2011). Rozhdenie slova: problemy psikhologii rechi i psikholingvistiki [The birth of the word: Problems of speech psychology and psycholinguistics]. Moscow, The Institute of Psychology of the Russian Academy of Science, $524 \mathrm{p}$.

Vinokurova, L.I., Filippova, V.V., Suleimanov, A.A., Grigor'ev, S.A. (2016). V ozhidanii ledokhoda: sotsial'nye aspekty razrushitel'nykh navodnenii v sel'skoi Iakutii (kon. XX - nach. XXI vv.) [Waiting for the ice-break: social aspects of devastating floods in rural Yakutia (late $20^{\text {th }}$ - early $21^{\text {st }}$ century)]. In Gumanitarnye issledovaniia v Vostochnoi Sibiri i na Dal'nem Vostoke [Humanitarian studies in Eastern Siberia and the Far East], 1 (35), 28-44.

Zamorshchikova, L.S., Romanenko A.A. Iakutskii assotsiativnyi slovar' [Yakut associative dictionary]. Available at: http://adictsakha.nsu.ru/dictback\#

Zamorshchikova, L.S., Khokholova, I.S. (2016). Documentation of endangered language: associative dictionary of the Yakut language. In International Multidisciplinary Scientific Conference on Social sciences and Arts (SGEM). Bulgaria, 211-216.

\title{
Образ водной стихии у жителей Якутии: опыт культуры
}

\author{
А.Н. Иконникова, И.С. Хохолова, \\ K.A. Пестерева \\ Северо-Восточный федеральньй университет \\ им. М.К. Аммосова \\ Российская Федераџия, Якутск
}

\begin{abstract}
Аннотация. Данная статья написана на стыке междисциплинарных наук, таких как языкознание, психолингвистика, культурология, история, этнология, социология, география. В работе использованы методы свободного и направленного ассоциативного эксперимента, семантического гештальта, анкетирования. В статье авторы раскрывают образы водной стихии у жителей Якутии на основе ассоциативного тезауруса якутского языка, а также социального опроса среди населения Якутии. В результате исследования было выявлено, что у современного населения образы водной стихии тесно взаимосвязаны с геоландшафтными и климатическими особенностями изучаемого края. Образ реки в языковом сознании якутов предстает как главный ориентир в пространстве и имеет движение и динамику во времени. Образ ледохода вытекает из представлений, связанных с климатическими условиями и ландшафтными особенностями региона, которые влияют на весенние (сезонные) природные стихии, а также с жизненной цикличностью - отпущением прошлого и началом новой жизни, характерной для южной тюркской культуры. Образ ледохода в языковом сознании якутян выражается через призму стихийности и опасности реки в целом.
\end{abstract}

Ключевые слова: образ реки, языковое сознание, река, гештальт, ледоход, стихия, наводнение, коренное население, Якутия.

Настоящее исследование проводится на средства гранта Российского научного фонда № 15-18-20047 «Онтология ландшафта: семантика, семиотика и географическое моделирование».

Научная специальность: 10.00 .00 — филологические науки. 